\title{
Management Practices of Sub-district Municipal Officials in Northern Thailand
}

\section{Prapaswat Ngamkana}

To Link this Article: http://dx.doi.org/10.6007/IJARBSS/v11-i12/11704

DOI:10.6007/IJARBSS/v11-i12/11704

Received: 17 October 2021, Revised: 21 November 2021, Accepted: 30 November 2021

Published Online: 16 December 2021

In-Text Citation: (Ngamkana, 2021)

To Cite this Article: Ngamkana, P. (2021). Management Practices of Sub-district Municipal Officials in Northern Thailand. International Journal of Academic Research in Business and Social Sciences, 11(12), 1641-1653.

\section{Copyright: @ 2021 The Author(s)}

Published by Human Resource Management Academic Research Society (www.hrmars.com) This article is published under the Creative Commons Attribution (CC BY 4.0) license. Anyone may reproduce, distribute, translate and create derivative works of this article (for both commercial and non0-commercial purposes), subject to full attribution to the original publication and authors. The full terms of this license may be seen at: http://creativecommons.org/licences/by/4.0/legalcode

Vol. 11, No. 12, 2021, Pg. 1641 - 1653

Full Terms \& Conditions of access and use can be found at http://hrmars.com/index.php/pages/detail/publication-ethics 


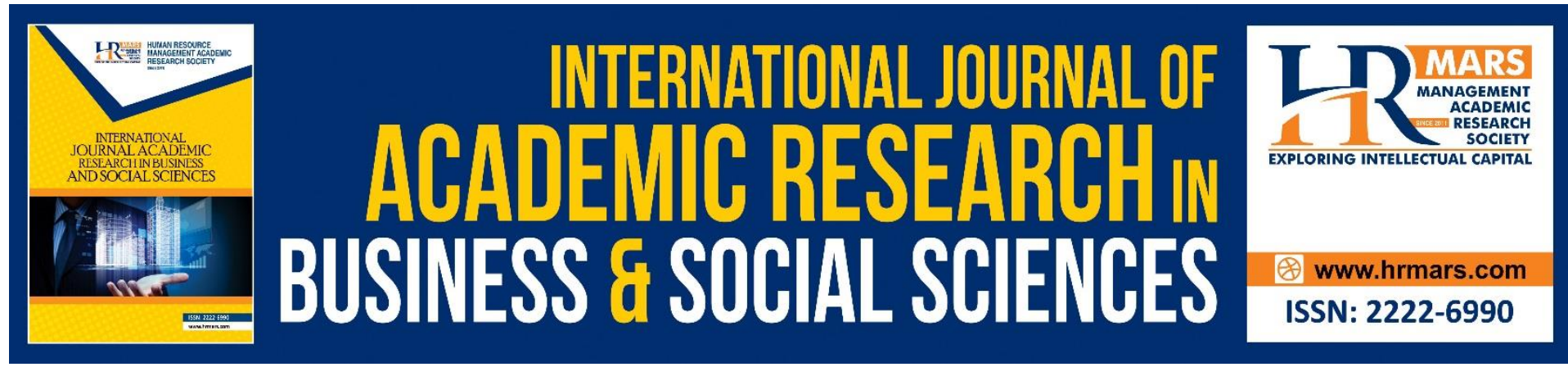

\title{
Management Practices of Sub-district Municipal Officials in Northern Thailand
}

\author{
Prapaswat Ngamkana (DPA) \\ DR International Training and Research, Thailand; Graduate School, Lyceum of the \\ Philippines University, Batangas City, Philippines \\ Email: prapaswatngamkana@gmail.com
}

\begin{abstract}
This study focused on management practices of officials of Sub-district Municipalities in Northern Thailand. Specifically, it is intended to describe the demographic profile of the Municipal Officials in terms of sex, age, level of education, and work experience; determine the management practices of the municipal officials in terms of infrastructure quality of life, community organization, planning, promotion investment, commerce and tourism, management and conservation of natural resources and environment, religion, art, culture, tradition and local knowledge, and administration and support of the mission of government agencies and local administration organizations; determine the level of supporting factors which consist of leadership, readiness, willingness to work, and employee participation. Data were collected via survey conducted on Municipal Officials of Sub-district in NorthernThailand with a total of 580 participants. The result of the study indicates that the supporting factors consist of leadership, readiness, willingness to work, and employee participation factors are correlated with management practices. The results of comparison on management practices along with the demographic profile had no significant difference when grouped according to sex while on management practices had significant difference when grouped according to age, education level, and work experience at the 0.05 level.
\end{abstract}

Keywords: Management of Sub-District, Supporting Factor, Leadership, Readiness, Willingness To Work, Employee Participation

\section{Introduction}

Management practice has been considered essential component of leadership in maintaining harmonious relationship between the people and its government especially in the municipal level. The decentralization happens in Thailand in 1997 which provides more role, functions and responsibilities to local administration. It gives more authority and empowerment for officials in the local level to think for themselves in conducting and managing activities which are more beneficial for the people. However, the officials on local administration have different management practices that sometimes hamper the achievement of the vision and goals of the municipality.

For the local government officials, planning is considered an important step to produce relevant ideas which are useful for future projections and decision of best practices. 
Through the process of thinking, it is necessary to establish the development plan of the local administration to improve the economic and social well-being of the community. Decisionmakers as leaders are involved in enhancement of infrastructure, quality of life, community organization, planning, promotion investment, commerce and tourism, management and conservation of natural resources and environment, religion, art, culture, tradition and local knowledge, and administration and support of the mission of government agencies and local administration organizations. They build connections with people and let them realize the National Economic and Social Development Plan, Provincial Development Plan, District Development Plan and Local Development Policy (Sinkhong, 2014). Leaders also gives importance to the strategic plan in ensuring the welfare of the community and in clarifying that the work is based on the intent of the Constitution of Thailand (2007) and the Ministry of Interior on the development plan of Local government in 2005 to provide opportunities for the people to participate in the government programs. The administrator of Municipality can either be developed locally or the community level which takes charge of the responsibility for having a sustainable prosperity and making a good living for the people.

The implementation of management practices goes hand-in-hand with leadership skills (Arellano et al., 2017; Laguador et al., 2013) as well as work-values (Aguado et al., 2015) of the municipal officials who are ready to perform duties especially the mayor of the district council. The trustees entrusted the management of the local community to perform such obligations for their communities under the Sub-district Municipality Act. Leadership is therefore an important factor for Sub-district administrators of Municipalities to make the performance of Sub-district Municipality successful according to the development strategy framework. The readiness of the municipal officials in serving the people is also an important supporting factor that could possibly determine the level of their management practices along with their willingness to work with proper motivation (Buenviaje et al., 2017; Refozar et al., 2017) and active participation of employees to the activities of the municipality gearing towards satisfaction (Mendoza et al., 2014) of the community.

The study is beneficial to describe the relationship between the supporting factors and the management practices of Sub-district Municipalities in Northern Thailand in providing useful information and in addressing relevant issues on managing and solving problems as well as in developing strategies to sustain the quality management in the municipal level. Producing relevant data is very important for administrator of Sub-district Municipality and chief executive and the Mayor to be used for decision making and developing effective plans for the community.

\section{Objectives of the Study}

Specifically, this study aims to describe the demographic profile of respondents in terms of sex, age, level of education, and work experience and Management of Sub-district Municipality in Northern-Thailand factor; test the significant difference on and Management of Sub-district Municipalities in Northern-Thailand when grouped according to profile variables; test significant relationship between and Management of Sub-district Municipality in Northern-Thailand with Supporting factors regards to leadership, readiness, willingness to work and employee participation and to propose a strategic plan of action to solving management system issues and provide important information for the development of Sub-district Municipality to quality management. 


\section{Method}

\section{Research Design}

This study used quantitative descriptive method of research to determine the management practices of officials in the Sub-district Municipalities in Northern Thailand along with the supporting factors using survey method.

\section{Participants}

In Northern of Thailand, there are nine (9) Provinces with a different number of Municipalities. Chiang Mai Province is the Province with the highest number of Sub-district Municipality. Therefore, the researcher selected Chiang Mai Province as the target area for this research. The target population of the study is composed of Sub-district Municipal officials of 116 Sub-district Municipalities in Chiang Mai Province in Northern Thailand. The sample size of the study is 580 participants with 100 percent retrieval rating. This is a limitation of the research for not all of Sub-district Municipalities in Northern-Thailand are willing to submit themselves to this kind of research undertaking. The accessibility of this research with other competitive media is also the main consideration in the choice of the research-participants.

The researcher used quota sampling and accidental sampling distributing the questionnaire to Municipal officials of Sub-district Municipalities in Chiang Mai Province; quota sampling and accidental sampling is a technique whereby chance the samples are included in the study on the basis of their availability at the time the sampling takes place.

\section{Data Gathering Instrument}

The researcher used self-made questionnaire which was constructed as a result of literature review and analysis of related studies. The instrument has three (3) parts. Part I dealt with demographic profile of Municipal officials; Part II dealt with Management Practices using seven (7) development strategies of Municipality consist of (1) infrastructure, (2) quality of life, (3) community organization, (4) planning, promotion investment, commercial and tourism, (5) management and conservation of natural resources and environment, (6) religion, art, culture, tradition and local knowledge, and (7) administration and support of the mission of government agencies and local administration; and Part III dealt with Supporting factors in terms of leadership, readiness, willingness to work and employee participation (Srithamma, 2013). The questionnaire was validated by the three (3) experts in the field of public administration and measurement and evaluation. The questionnaire was also tested its reliability with cronbach's alpha value of 0.812 which signifies that the instrument has a good internal consistency.

The research instrument utilized the five (5) point rating scale (Likert, 1967) which was used to measure respondents' Management Practices of Sub-district Municipalities in Northern Thailand and the supporting factors. Responses to Part II and Part III were quantitatively measured using an item choice of options with one (1) as the lowest and 5 as the highest.

\section{Procedure}

The researcher visited the mayor of Sub-district Municipality in Chiang Mai Province to talk informally for collecting information regarding Supporting factors and Management of Sub-district Municipality in Northern Thailand. Data were collected via a survey conducted among Municipal officials of Sub-district Municipalities in Chiang Mai Province in Northern 
Region in Thailand. A total of 580 questionnaires were distributed and all questionnaires were returned and used for analysis. The number of questionnaires returned represents about 100 percent of the total number of questionnaires distributed. In addition, the researcher also scheduled an interview with at least ten (10) municipal officials to validate the result of the survey. The respondents were informed about the purpose of the study and the confidentiality of their responses. Names of the respondents were not collected to ensure the anonymity of their responses.

\section{Data Analysis}

Quantitative data analysis was conducted using weighted mean to measure the level of management practices and supporting factors, while frequency count and percentage were used to describe the demographic profile of the respondents. The Statistical test used for the study is parametric test because the nature of data is normally distributed based on the Shapiro Wilk test with $\mathrm{p}$-value of greater than 0.01 . Therefore, t-test and One Way ANOVA were utilized to test the significant differences on the major variables when grouped according to profile and Pearson Correlation Coefficient at 0.05 level of significance was used to test the significant relationship between management practices and supporting factors. The value and the corresponding verbal interpretation are the following: 4.50-5.00: Strongly Agree; 3.50-4.49: Agree, 2.50-3.49: Moderately Agree; 1.50-2.49: Disagree; 1.00-1.49: Strongly Disagree.

\section{Result and Discussion}

Table 1. Frequency and percentage of the respondents' profile $(\mathrm{N}=580)$

\begin{tabular}{lcc}
\hline \multicolumn{1}{c}{ Profile Variables } & $\mathbf{f}$ & $\%$ \\
\hline Sex & 341 & 58.80 \\
Male & 239 & 41.20 \\
Female & & \\
Age & 98 & 16.60 \\
Less than 25 years old & 172 & 29.70 \\
26 to 35 years old & 123 & 21.20 \\
36 to 45 years old & 76 & 13.00 \\
46 to 55 years old & 113 & 19.50 \\
Over 55 years old & & \\
Level of education & 229 & 39.50 \\
Undergraduate & 262 & 45.20 \\
Bachelor Degree & 895 & 15.30 \\
Post-graduate Degree & & \\
Length of Work Experience & 53 & 9.10 \\
1 - 5 Years & 323 & 55.70 \\
6 - 10 Years & 105 & 18.10 \\
11 -15 Years & 99 & 17.10 \\
Over 15 Years
\end{tabular}

Table 1 describes the distribution of the respondents by sex, age group, level of education, and working experience with the frequency and percentage of the respondents. Distribution of the respondents by sex shows that the male respondents are three hundred and forty one (341) or 58.80 percent against female respondents with 239 or 41.20 percent. 
There are more male respondents in the study, but the study signifies that both males and females can work in municipality because there are many types of municipal work, because some jobs are done by male and female and some jobs are not suitable for female, such as mechanical work, construction work that requires labor. In this research, it was found that most of the municipal employees are male.

The results also showed that majority of the respondents belongs to 26-35 years old age bracket with 172 or 29.70 percent followed by the 123 or 21.20 percent of the respondents within the age group of 36-45 years old. Meanwhile, the age group of $46-55$ year old has the least number of participants with 76 or 13.00 percent.

Distribution of the respondents by level of education shows that there are 229 or 39.50 percent of the respondents hold undergraduate degree certificate, 262 or 45.20 percent of the respondents are holders of bachelor's degree certificate, and 89 or 15.30 percent of the respondents hold the post-graduate degree certificates. Majority of the respondents hold undergraduate degree which shows that they are working as technicians who serve the people with supervisors. Therefore, this type of job does not require high level of education. Distribution of the respondents by working experience shows that there are 53 respondents or 9.10 percent of them have a length of service within 1-5 years, 323 or 55.70 percent of the respondents have 6 to 10 years of working experience while 105 or 18.10 percent of the them have 11-15 years, and 99 or 17.10 percent of the respondents have more than 15 years of working experience based on the findings of the survey conducted.

Table 2. Management Practices of Officials in Sub-district Municipality in Northern Thailand

\begin{tabular}{|c|c|c|c|}
\hline & WM & VI & Rank \\
\hline 1. Infrastructure. & 4.62 & itrong Agree & 2.5 \\
\hline 2. Quality of life. & 4.62 & itrong Agree & 2.5 \\
\hline 3. Community organization. & 4.59 & itrong Agree & 5.5 \\
\hline $\begin{array}{l}\text { 4. Planning, promotion investment, commerce and } \\
\text { tourism. }\end{array}$ & 4.60 & trong Agree & 4 \\
\hline $\begin{array}{l}\text { 5. Management and conservation of natural } \\
\text { resources and environment. }\end{array}$ & 4.64 & itrong Agree & 1 \\
\hline $\begin{array}{l}\text { 6. Religion, art, culture, tradition and local } \\
\text { knowledge. }\end{array}$ & 4.59 & itrong Agree & 5.5 \\
\hline $\begin{array}{l}\text { 7. Administration and support of the mission of } \\
\text { government agencies and local administration } \\
\text { organizations. }\end{array}$ & 4.57 & itrong Agree & 7 \\
\hline
\end{tabular}

Table 3 presents the level of management practices of officials in Sub-district Municipality in Northern-Thailand. The results showed that the respondents have very high level of response on the management practices $(C M=4.60)$. The respondents strongly agreed on the management practices related infrastructure (WM=4.62), quality of life $(W M=4.62)$, community organization $(W M=4.59)$, planning, promotion investment, commerce and tourism $(W M=4.60)$, management and conservation of natural resources and environment $(W M=4.64)$, religion, art, culture, tradition and local knowledge $(W M=4.59)$, and administration and support of the mission of government agencies and local administration organizations $(W M=4.57)$. 
This is a strong indication that development strategies are important to use as a guide for community development to generate ideas and utilize the ability of the people through active participation. This may somehow improve their quality of life and experience better opportunities through the cooperation of the people and the government. The study also revealed that in terms of infrastructure, the municipality performs water and land maintenance as well as the maintenance of electricity or lighting, and improvement of service facilities. The local administration also supports the promotion of quality of life especially the advocacy on the development of women, children, juveniles, the elderly and the disabled.

There are programs for disease prevention and control but there is a need improve the crowded community and management of housing as well as taking care of society and keeping of peace and order in the community. There are also programs related to prevention and mitigation, disaster and the cleanliness and orderliness of the country as well projects related to planning, promotion investment, commerce and tourism.

There is a wide collection of solid waste and maintenance of sewage system. Planning for the promotion of investment, commerce and tourism. Promote training and career. The maintenance and promotion of the occupation of the people and improvement of the planning of commercial investment are also being conducted. The people are also wanted to provide strong support in the tourism sector in Northern Thailand by maintaining natural resources and environment; keeping clean waterways, walkways and public spaces, as well as sustaining the proper waste and solid waste disposal (Laguador et al., 2013). They also wanted to solve the problem on pollution and provide strong support for the environmental protection and preservation of the natural resources as well as taking care of ancient archaeological sites. In Northern-Thailand, there is a lot of scenery and fruits and vegetables that are supported by the government.

In terms of religion, art, culture, tradition and local knowledge, cultural traditions have already existed for hundreds of years and considered ancient. The municipality has encouraged the people and the community to conserve and maintain these traditions and promote local wisdom and education. They also observed the need to promote education, religion and culture to the local community.

There are also local programs that support the achievement of the mission of government agencies and local administration. The municipality manages the work that is transparent. The municipality supports the mission of government agencies and local government organizations to achieve their goals. Good relationship between officials and management and good coordination with other local organizations and people, and improvements to the management of the municipality should be emphasized. It is important to have a clear understanding of what is happening in the community and how it will affect the lives and wellbeing of local people.

Table 3. Summary of Supporting factors

\begin{tabular}{lllc}
\hline \multicolumn{1}{c}{ Supporting factors } & WM & VI & Rank \\
\hline 1. Leadership & 4.63 & Strong Agree & 1.5 \\
2. Readiness & 4.60 & Strong Agree & 4 \\
3. Willingness to work & 4.61 & Strong Agree & 3 \\
4. Employee participation & 4.63 & Strong Agree & 1.5 \\
\hline
\end{tabular}

Composite Mean

$4.61 \quad$ Strong Agree

Table 3 presents the supporting factors in terms of leadership, readiness, willingness to work and employee participation. The composite mean score of $4.61 \mathrm{implies}$ that there is 
a high level of supporting factor in the discharge of their duties and responsibilities as observed by the respondents. Leadership ( $W M=4.63)$ and employee participation $(W M=4.63)$ are considered with the highest mean scores from the supporting factors followed by willingness to work ( $W M=4.61)$ and readiness ( $W M=4.60)$.

This is a strong indication that leadership and employee participation are important and leading factors in supporting the management practices of the municipal officials. This involvement is linked to the process of taking individual responsibility or the process of change into the overall picture. and according to kornthong (2009) who mentioned that participation refers to mental and emotional involvement. People are given the opportunity to make decisions and become responsible in solving the problem of the community and develop the ability to control resources, participate in democratic activities and provide authority to take responsibility. Employee participation is very important factor for administration. Municipal service operation works in order to achieve effectiveness in the management of public service.

According to the research done in Thailand, Srithamma (2013) found that Sub-district municipal officials had a strong belief and a sense of purpose and job creation. Participate in the creation and improvement of a good corporate work environment (Dixon et al., 2019; Vanessa et al., 2019). It should be improved to promote the initiative of Municipal officials while creative skill of the officials also provides knowledge to benefit the operation. Harmony in the organization also produces success. Leaders need support and commitment from employees to achieve their goals. Leaders also engage others in the creation of a mission, vision and clearly communicate the differences and benefits that the employees will gain from future success. They can also be motivated and excited by this new direction to create an effective working system or to move the organization in the same direction.

Every level of the organization also works in the same direction to achieve the same objective. As leaders need to change the system, the work procedures and organizational structure should be in accordance with the purpose of the organization. If the leaders give the employees the power to work seriously, they will make the atmosphere of work who trust each other. Interpersonal and intrapersonal communication (Buenviaje et al., 2016; Habib \& Mucha, 2018) produces new and effective results. This is because members of the group or Municipal officials can express their opinions and potentials freely. Leaders need to create conditions that will stimulate creativity and unleash resourcefulness. Unique talents and potential exist in every individual. This approach enables the people to perform better in the organization.

Table 4. Test of Difference on Management Practices According to sex

\begin{tabular}{|c|c|c|c|c|c|c|}
\hline Variable & \multicolumn{3}{|c|}{ Management Practices } & \multirow{2}{*}{ Df } & \multirow{2}{*}{$\mathbf{T}$} & \multirow{2}{*}{$p$} \\
\hline Sex & $\mathbf{N}$ & Mean & S.D. & & & \\
\hline Male & 341 & 4.60 & .218 & 546.252 & -1.134 & 257 \\
\hline Female & 239 & 4.62 & .194 & & & \\
\hline Total & 580 & 4.60 & .208 & & & \\
\hline
\end{tabular}

${ }^{*} p<0.05$ Significant at the 0.05 level (2-tailed).

Table 4 presents the difference on Management practices when grouped according to sex. The result revealed that there is no significant difference on management practices between males and females $(t=-1.134, p=.257)$ at 0.05 alpha level. Because every Municipal official complies with their obligations as assigned. Therefore, whether they are female or 
male, they manage the municipality very well. This is in accordance with the municipal law that defines roles and responsibilities. Sex has significant difference from the study of Weerapan (2012); Srithamma (2013). However, the present study shows no significant difference based on the responses of Sub-district Municipal officials about their management practices.

Table 5. Test of Difference on Management Practices According to Age group

\begin{tabular}{clrrrrr}
\hline Variable & Variance & $\begin{array}{c}\text { Sum of } \\
\text { Square }\end{array}$ & Df & $\begin{array}{c}\text { Mean } \\
\text { Square }\end{array}$ & F & $\boldsymbol{p}$ \\
\hline Age group & Between & 2.185 & 4 & .546 & $13.726^{*}$ & $<.01$ \\
& Within & 22.885 & 575 & .040 & & \\
\cline { 2 - 7 } & Total & 25.071 & 579 & & & \\
\hline \hline
\end{tabular}

${ }^{*} p<0.05$ Significant at the 0.01 level (2-tailed).

Table 5 shows significant difference in the Management practices of Sub-District Municipality in Northern-Thailand when grouped according to age group $(f=13.726, p<0.01)$. This signifies that those respondents who are less than 25 years old have significantly higher response on management practices than older group of respondents. Younger officials have very ideal perspective on management practices that brings them positive views on how they will manage the municipality. Older officials have seen already different aspects of public service therefore, they offer suggestions for areas that need continuous improvement.

Table 6. Test of Difference on Management Practices According to level of education

\begin{tabular}{rlrrrrr}
\hline Variables & Variance & $\begin{array}{c}\text { Sum of } \\
\text { Square }\end{array}$ & Df & $\begin{array}{c}\text { Mean } \\
\text { Square }\end{array}$ & $\mathbf{F}$ & $\boldsymbol{p}$ \\
\hline $\begin{array}{r}\text { Level of } \\
\text { education }\end{array}$ & Between & .461 & 2 & .230 & $5.401^{*}$ & .005 \\
\cline { 2 - 7 } & Within & 24.610 & 577 & .043 & & \\
\cline { 2 - 6 } & Total & 25.071 & 579 & & & \\
\hline \hline
\end{tabular}

Table 6 reveals that significant difference exists on Management practices of SubDistrict Municipal officials in Northern-Thailand when grouped according to level of education $(f=5.401, p=.005)$. The result showed that those respondents with undergraduate level of education have significantly higher response on management practices than those respondents with higher educational attainment based on the Scheffe test result. Municipal officials with higher level of education have the ability to think and analyst problems. They can solve problems in the management of various aspects than those respondents who are bachelors' degree holders. They see more challenges and issues in wider perspectives that lead them to have lower views in management practices of the municipal officials. 
INTERNATIONAL JOURNAL OF ACADEMIC RESEARCH IN BUSINESS AND SOCIAL SCIENCES Vol. 11, No. 12, 2021, E-ISSN: 2222-6990 ๑ 2021 HRMARS

Table 7. Test of Difference on Management Practices According to working experience

\begin{tabular}{rlrrrrr}
\hline \multirow{2}{*}{ Variable } & Variance & $\begin{array}{l}\text { Sum of } \\
\text { Square }\end{array}$ & df & $\begin{array}{c}\text { Mean } \\
\text { Square }\end{array}$ & F & \multicolumn{1}{c}{$\boldsymbol{p}$} \\
\hline \multirow{2}{*}{$\begin{array}{r}\text { Working } \\
\text { experience }\end{array}$} & Between & .654 & 3 & .218 & $5.141^{*}$ & .002 \\
\cline { 2 - 8 } & Within & 24.417 & 576 & .042 & & \\
\cline { 2 - 6 } & Total & 25.071 & 579 & & & \\
\hline \hline
\end{tabular}

Table 7 reveals the significant difference on management practices when the respondents are grouped according to working experience $(f=5.141, p=.002)$. Result revealed that those respondents with 11-15 years of working experience have significantly higher response on management practices compared to other groups.

Table 8. Correlation coefficients between Management Practice and Supporting factors

\begin{tabular}{lcccc}
\hline \multicolumn{1}{c}{ Variables } & Mean & S.D. & r-value & Sig. \\
\hline Management Practices & 4.60 & .208 & & \\
Supporting Factors & 4.61 & .234 & $.928^{* *}$ & $<.01$ \\
$\quad$ Leadership & 4.63 & .269 & $.559^{* *}$ & $<.01$ \\
Readiness & 4.60 & .325 & $.707^{* *}$ & $<.01$ \\
Willingness to work & 4.61 & .299 & $.753^{* *}$ & $<.01$ \\
Employee participation & 4.63 & .389 & $.658^{* *}$ & $<.01$ \\
\hline \multicolumn{1}{c}{ Total } & & & &
\end{tabular}

*Correlation is significant at the .05 level; ${ }^{* *}$ Correlation is significant at the .01 level.

Table 8 presents the relationship between management practices and supporting factors in terms of leadership, readiness, willingness to work, and employee participation. Significant strong positive correlation exists between management practices and supporting factors $(r=.928, p<.01)$ and there were four correlated positive strong associations between Management practices with leadership factor $(r=.559, p<.01)$, readiness factor $(r=.707, p<.01)$, willingness to work $(r=.753, p<.01)$, and employee participation factor $(r=.658, p<.01)$. This result shows that management practices and supporting factors are important components in managing Sub-district Municipalities. The results of this study support that leadership, readiness, willingness to work and employee participation are impact Management of Subdistrict Municipality at high level. Because municipal officials are responsible for the administration of the community within their capacity to efficiently serve the public. Municipal leaders have high level of leadership skills that can contribute to the internal and external quality. They can also convince employees to participate in the work-related activities with enthusiasm who are ready to work in serving people all the time.

\section{Proposed Management Strategies}

The proposed management strategies aim to provide a support for the community in enhancing the quality of life of the people by improving the public infrastructure and community organization; strengthening the planning, promotion investment, commerce and tourism; reinforcing the management and conservation of natural resources and environment; promoting religion, art, culture, tradition and local knowledge; and supporting the administration to achieve the mission of government agencies and local administration organizations. These strategies will be made possible through the active involvement of 
Mayor, Municipal Council, permanent secretary and all the people in the community with appropriate funding allocation.

Table 8. Proposed Management Strategies for Sub-district Municipalities in Northern Thailand

\begin{tabular}{|c|c|}
\hline $\begin{array}{l}\text { Key Result } \\
\text { Areas }\end{array}$ & Strategies \\
\hline Infrastructure & $\begin{array}{l}\text { 1. Revise their local development plans by providing and maintaining } \\
\text { land-based waterways and drainage in the community. } \\
\text { 2. Improve market management and enough parking for tourists. } \\
\text { 3. Improve utilities and other public construction }\end{array}$ \\
\hline Quality of life & $\begin{array}{l}\text { 1. Improve the education of the child center with modern teaching } \\
\text { materials. } \\
\text { 2. Improve the social work process. And improving the quality of life } \\
\text { for children, women, the elderly and the underprivileged. } \\
\text { 3. 3. Organize career promotion activities for the elderly. And to } \\
\text { participate in sports activities in the community more. }\end{array}$ \\
\hline $\begin{array}{l}\text { Community } \\
\text { organization }\end{array}$ & $\begin{array}{l}\text { 1. Improvement of slums and management of housing } \\
\text { 2. The maintenance of recreation facilities and sprots promotion. } \\
\text { 3. Promotion of democracy, equality and freedom of the people, and } \\
\text { active participation of people in local development. }\end{array}$ \\
\hline $\begin{array}{l}\text { Planning, } \\
\text { promotion } \\
\text { investment, } \\
\text { commerce } \\
\text { and tourism }\end{array}$ & $\begin{array}{l}\text { 1. Promote and develop farmers' potential and develop technology } \\
\text { and innovation in production and business. } \\
\text { 2. Infrastructure development for production facilities and business } \\
\text { enterprises that also support in finding new markets for agricultural } \\
\text { products. } \\
\text { 3. Development of strong linkage between production and business } \\
\text { operations to the international level. }\end{array}$ \\
\hline $\begin{array}{l}\text { Management } \\
\text { and } \\
\text { conservation } \\
\text { of natural } \\
\text { resources and } \\
\text { environment }\end{array}$ & $\begin{array}{l}\text { 1. Development of natural and environmental resources to be } \\
\text { beautiful and sustainable. With technology and innovation. } \\
\text { Promote and develop tourism and health services linking } \\
\text { communities and localities. } \\
\text { 2. Campaign for the people and youth to be conscious of the care and } \\
\text { conservation of nature and the environment. } \\
\text { 3. Development of potential local and community tourism activities by } \\
\text { providing links to public relations and tourism marketing and health } \\
\text { services. }\end{array}$ \\
\hline $\begin{array}{l}\text { Religion, art, } \\
\text { culture, } \\
\text { tradition and } \\
\text { local } \\
\text { knowledge }\end{array}$ & $\begin{array}{l}\text { 1. Strengthening the society, maintaining cultural identity. } \\
\text { 2. Development of regional education center with excellence in } \\
\text { education and learning where the local wisdom can be brought } \\
\text { down to practice in the community. } \\
\text { 3. Promotion of moral and moral activities of the people and equitable } \\
\text { access to society. }\end{array}$ \\
\hline $\begin{array}{l}\text { Administration } \\
\text { and support of } \\
\text { the mission of } \\
\text { government }\end{array}$ & $\begin{array}{l}\text { 1. Development of internal security plan that focuses on integrating all } \\
\text { sectors with government support } \\
\text { 2. Development of prevention and solutions to security and drug } \\
\text { problems. }\end{array}$ \\
\hline
\end{tabular}




\begin{tabular}{|c|c|}
\hline $\begin{array}{l}\text { agencies and } \\
\text { local } \\
\text { administration } \\
\text { organizations }\end{array}$ & $\begin{array}{l}\text { 3. Development of disaster prevention and mitigation systems } \\
\text { through community participation. }\end{array}$ \\
\hline
\end{tabular}

\section{Conclusion and Recommendation}

Majority of the respondents is composed of male respondents with age bracket from 26 to 35 years old and holders of bachelor's degree certificate having work experience within 6 to 10 years. The result revealed that the municipal officials have very high level of supporting factors and management practices in the Sub-district Municipalities in Northern Thailand. The results of comparison of Management practices along demographic had no significant difference when grouped according to sex. The Management of Sub-district Municipalities in Northern-Thailand had significant difference group of age group, education level, and working experience at the 0.05 level. Younger respondents have higher response on the management practices than those who are 46 years old and above. Younger generations have different outlooks and perspective how they see the new style managing the organization with dynamic vision and future's thinking approach to leadership. Meanwhile, the result of relationship between Supporting factors and Management practices of Sub-district Municipalities in Northern-Thailand has significantly positive strong correlation along with the supporting factors in terms of leadership, readiness, willingness to work, and employee participation. The result of the study will be useful for the improvement of the quality of management practices of Sub-district Municipalities in accordance with the expectations for public service development strategies of Municipalities in Northern Thailand.

The proposed management strategy is recommended to be discussed during meetings with top mayor, Municipal Council and Permanent Secretary, and chief of departments of Sub-district Municipalities to affirm the result of this research and used as guideline to develop strategic plan. The study is limited to the Sub-district Municipalities in Northern Thailand. Similar study may be conducted in other parts of Thailand to cover other areas for the generalization of the findings among local municipal officials. and which maybe the baseline of other research to investigate other variable not covered in other variables. Job performance of municipal officials and studies related to the efficiency and effectiveness of local governance to the welfare of the community may be conducted for future investigation. Developing a strategic plan is also recommended in improving the leadership and management skills of municipal officials to continuously offer effective public services where people are satisfied in the programs and projects provided to them.

\section{References}

Aguado, C. L., Garcia, O. B., Laguador, J. M., \& Deligero, J. C. L. (2015). Teaching performance and extent of work values among faculty members in one Asian Maritime Academy. International Journal of Management Sciences, 5(12), 805-816.

Arellano, J. M., Miña, J. M., Villas, E. M., \& Laguador, J. M. (2017). Development Needs Analysis on the Confidence and Leadership Capabilities of Maritime Students with High and Low Academic Performance. Asia Pacific Journal of Maritime Education, 3(1).

Buenviaje, M. G., Morcilla, G. P., FernanRefozar, R., Macalalad, J. A., \& Laguador, J. M. (2016). Role of Effective Communication in the Organizational Commitment and Employee Behavior as Input to Human Resource Management. Quarterly Journal of Business Studies, 2(4), 193-200. 
Buenviaje, M. G., Refozar, R. F. G., Encio, H. A., Perez, M. P., \& Laguador, J. M. (2017). Leader motivating language affecting faculty members' work performance from a private academic institution in the Philippines. Asia Pacific Journal of Education, Arts and Sciences, 4(3), 121-130.

Weerapan, C. (2012). The satisfaction of the people towards the service of the Ban Khai Subdistrict Administrative Organization, Phan Thong District, Chon Buri Province. College of Public Administration Burapa university.

Dixon, S. M., Searcy, C., \& Neumann, W. P. (2019). Reporting within the corridor of conformance: Managerial perspectives on work environment disclosures in corporate social responsibility reporting. Sustainability, 11(14), 3825.

Habib, A., \& Mucha, S. M. (2018). The Lifecycle and Effective Communication of CSR to the Stakeholder and the Public. International Journal of Economics, Business and Management Studies, 5(1), 1-8.

Kornthong, K. (2009). Parental Involvement in Education. The first level of education. Primary Child Development Center Phra Pradaeng District, Samut Prakan Province, Faculty of Education, Rajabhat University.

Sinkhong, K. (2014). The people participation in strategy plan development of Thapho Subdistrict administrative organization, Muang District, Phitsanulok Province. Graduate School Mahachulalongkornrajavidyalaya University Bangkok, Thailand

Laguador, J. M., Mandigma, L. B., \& Agena, E. (2013). Community Extension Service In The Waste Management Practices Of Brgy. Wawa Residents In Batangas City. Academic Research International, 4(4), 141.

Laguador, J. M., Velasquez, M. E., \& Forendo, K. C. (2013). Leadership Capability Assessment of Senior Industrial Engineering Students. International Journal of Basic Applied \& Social Sciences, 1(3), 7-12.

Likert, R., \& Likert, J. (1976). New way of Managing Conflict. New York: McGraw-Hill.

Mendoza, R. O., Laguador, J. M., \& Buenviaje, M. G. (2014). Organizational satisfaction and work engagement among non-teaching personnel of an Asian university. Asian Journal of Management Sciences and Economics Vol, 1(1).

Srithamma, N. (2013). Management of Local Government in the Central Region. Dissertation. Human Resource Development Administration. Pathumthani University.

Refozar, R. F. G., Buenviaje, M. G., Perez, M. P., Manongsong, J. L., \& Laguador, J. M. (2017). Extent of leader motivating language on faculty members' job satisfaction from a higher education institution. Asia Pacific Journal of Education, Arts and Sciences, 4(3), 99-107.

Vanesa, Y. Y., Matondang, R., Sadalia, I., \& Daulay, M. T. (2019). The Influence Of Organizational Culture, Work Environment And Work Motivation On Employee Discipline In PT Jasa Marga (Persero) TBK, Medan Branch, North Sumatra, Indonesia. American International Journal of Business Management (AIJBM), 37-45. 